\title{
COMPARATIVE STUDY OF ZETA AND SINGLE STAGE HIGH VOLTAGE GAIN DC-DC CONVERTERS
}

\author{
J.S. Nancy Mary \\ Assistant Professor, Department of Electrical and Electronics Engineering, \\ Loyola - ICAM College of Engineering and Technology, Chennai, INDIA \\ Dr. K. Mala \\ Professor, Department of Electrical and Electronics Engineering, \\ Easwari College of Engineering, Chennai, INDIA
}

\begin{abstract}
Solar energy will be the important source of energy for the future. Solar cells transform energy from an essentially unlimited source sun. PV system virtually zero running cost energy is the input source of power. It is environment friendly. The DC$D C$ converters are used to increase the efficiency of PV system. This paper envisages the comparison of the two topologies of two converters; Zeta and high voltage gain $D C-D C$ Converter.
\end{abstract}

Keywords: Zeta Converter, Dickson Charge Pump, high voltage gain DC-DC Converter

Cite this Article: J.S. Nancy Mary and Dr. K. Mala, Comparative study of ZETA and Single Stage High Voltage Gain DC-DC Converters, International Journal of Electrical Engineering \& Technology, 10(3), 2019, pp. 45-55.

http://iaeme.com/Home/issue/IJEET?Volume=10\&Issue $=3$

\section{INTRODUCTION}

Renewable energy often provides generation of electricity, transport fuels, air cooling and water heating. It provides electric generation world-wide. Solar and wind energy provides the significant share of electricity. [1-2] The deployment of renewable energy efficiency and resources due to climate change results in renewable energy products in large scale, which is suited to remote and rural areas, and developing countries, where energy is often crucial in human development. Due to higher efficiency and reliability at an improved power quality, DC distribution systems was better than the AC distribution systems. [3] They offer a simpler integration of renewable energy and energy storage systems. Currently, telecom centres, data centres, commercial buildings, residential buildings, and micro grids are among the emerging examples of dc distribution systems. The Zeta converter provides a positive output voltage above or below the output voltage. This converter needs two inductor and capacitor. This will regulate the voltage. [4] 
A single stage high-voltage-gain dc-dc converter is proposed which resembles Dickson charge-pump based voltage multiplier on output side and a two-phase interleaved boost converter on its input side. This converter offers continuous input current, which makes it more appealing for the integration of renewable sources like solar panels. This converter is capable of drawing power from either a single source or two independent sources. Depending upon the output voltage stages can be added. Furthermore, the VM used offers low voltage ratings for capacitors that potentially leads to size reduction. [5]

\section{ZETA CONVERTER}

The circuit of ZETA converter is shown below. It has Capacitors CC and COUT, inductors L1 and L2, MOSFET acting as switch and a diode. Consider the Zeta converter acting in continuous conduction mode. The modes of operation is given for Q is ON and Q is OFF.[69]

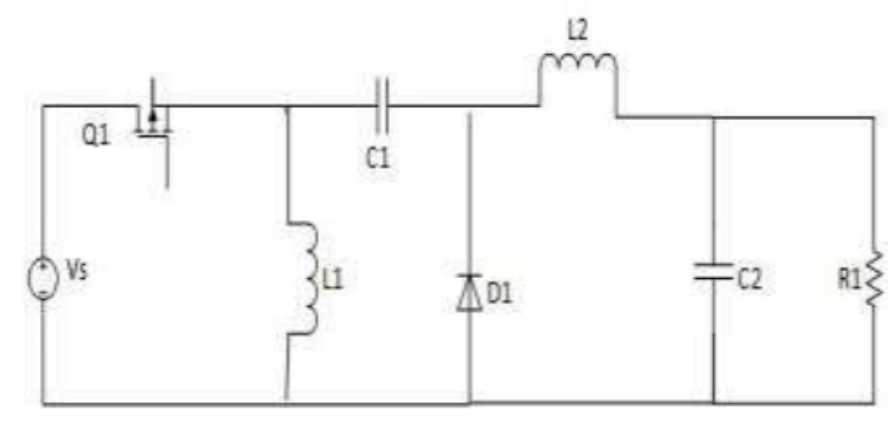

Figure 1 :Zeta Converter

\section{Mode 1}

When Q ON; Capacitor $\mathrm{C}_{\mathrm{C}}$ charged to $\mathrm{V}_{\mathrm{OUT}}$ and it is connected in series with $\mathrm{L}_{2}$, so the voltage across $\mathrm{L}_{1}$ is $\mathrm{V}_{\text {IN }}$ and Diode $\mathrm{D}$ sees $\mathrm{V}_{\text {IN }}$ and $\mathrm{V}_{\text {OUT. }}$.

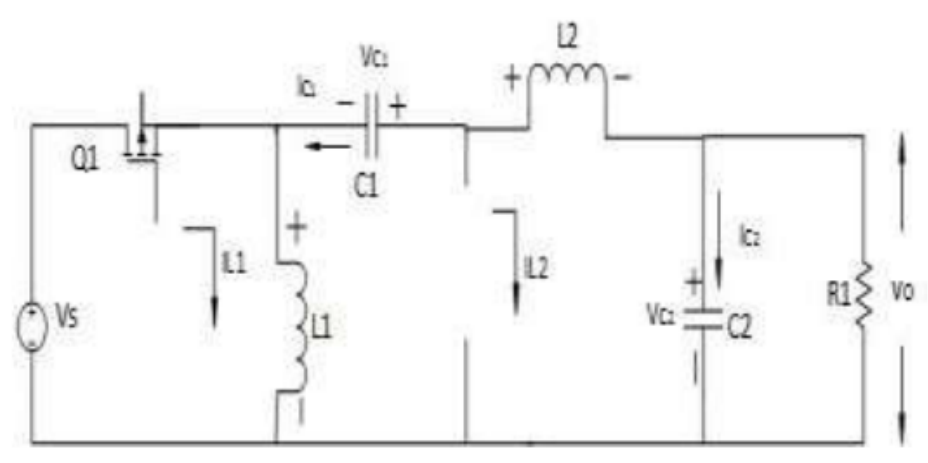

Figure 2 Mode 1 of Zeta Converter

$$
\begin{aligned}
& L_{1} * \frac{D i L_{1}}{d t}=V_{s} \\
& D i \frac{L_{2}}{d t}=\frac{V s}{L_{2}}+\frac{V C_{1}}{L_{2}}-\frac{V C_{2}}{L_{2}} \\
& C_{2} * \frac{D V_{C 2}}{d t}=i_{L 1}
\end{aligned}
$$




\section{Mode 2}

When $\mathrm{Q}$ OFF; the voltage across L1must be $\mathrm{V}_{\text {OUT }}$, the voltage across $\mathrm{Q}$ is $\mathrm{V}_{\mathrm{IN}}+\mathrm{V}_{\text {OUT }}$, therefore the voltage across $\mathrm{L}_{1}$ is $-\mathrm{V}_{\text {OUT }}$ relative to the drain of Q1.

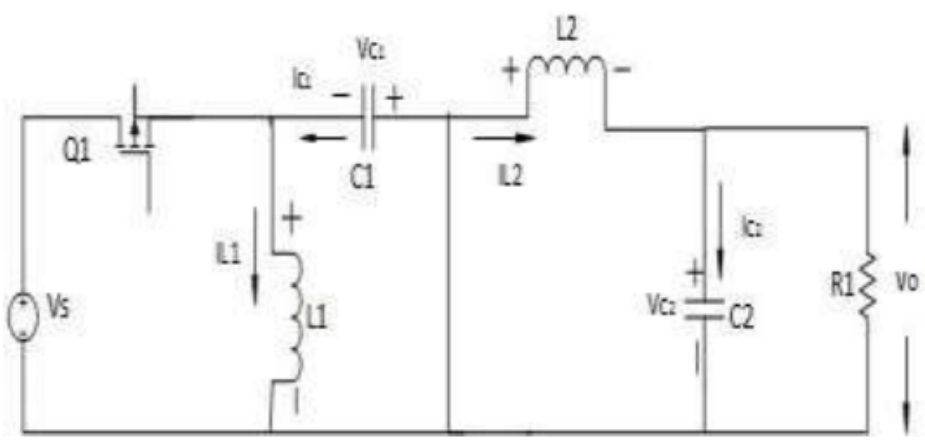

Figure 3 Mode 1 of Zeta Converter

By kirchoff's voltage law, voltage across inductor $\left(\mathrm{L}_{1}\right)$ is given by,

$L_{1} \frac{D i_{L 1}}{d t}=-V_{1}$

Voltage across inductor $\left(\mathrm{L}_{2}\right)$ is given by,

$L_{1} \frac{D i_{L 2}}{d t}=-V_{L 2}$

By applying kirchoff's current law, current through the capacitor $\mathrm{C}_{1}$ is,

$i_{L 1}=C_{1} * \frac{D V_{C 1}}{d t} \quad \ldots$

$D=\frac{V_{O}}{V_{O^{+}}+V_{S}}$

By volt second balance,

$V_{S} * T_{O N}+\left(V_{S}-V_{C 1}\right) * T_{O F F}=0 \ldots$

\section{BASIC DICKSON CHARGE PUMP DESIGN}

The basic configuration of a Dickson charge pump is shown in Figure. It consists of a large number of identical stages, each containing a diode and a capacitor, where the bottom plates of the capacitors in consecutive stages. Charge is transferred from one capacitor yielding an output voltage that can be much higher than the input voltage. In a real application, a feedback control loop is added to the circuit in order to maintain the output voltage very stable and independent of system parameters or load characteristics. ${ }^{[10]}$

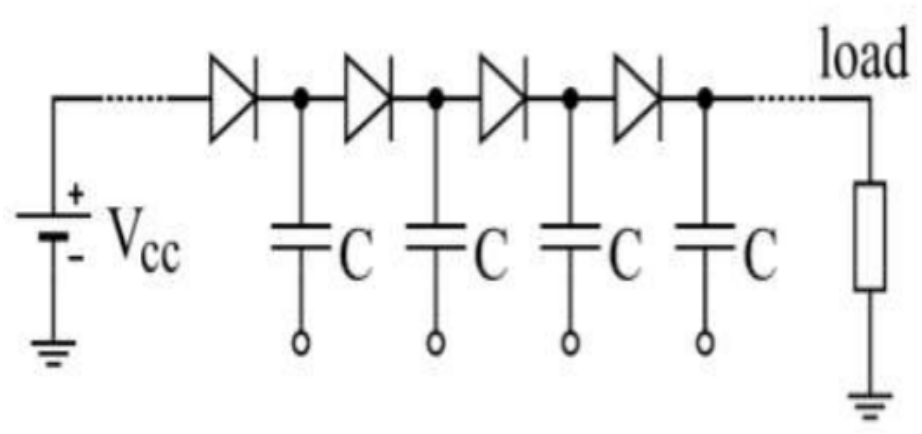

Figure 4 Dickson Charge Pump 


\section{HIGH VOLTAGE GAIN DC-DC CONVERTER}

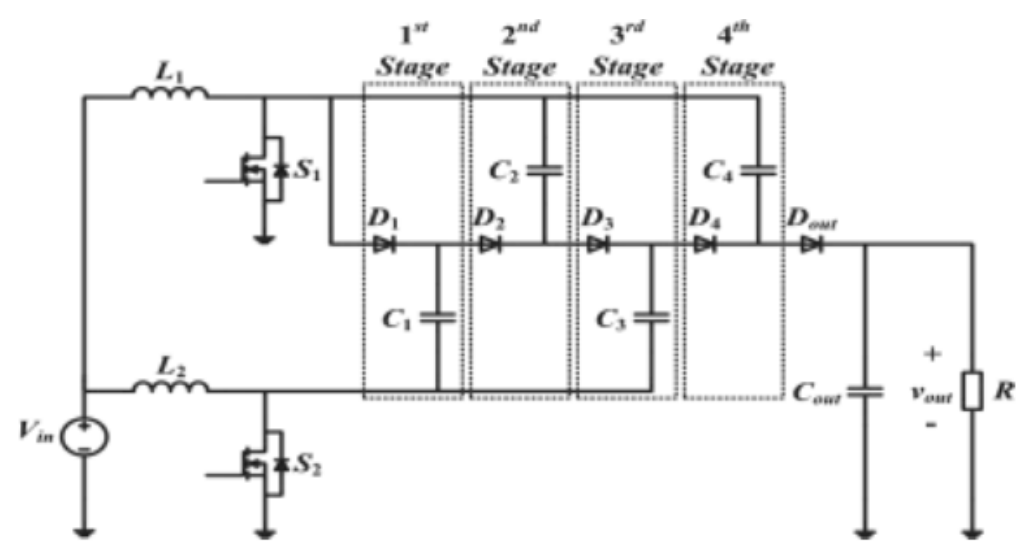

Figure 5 High Voltage gain DC-DC Converter

The energy storage cell - based converters offers low voltage. The switched capacitor based network converter has a discontinuous input ripple due to series - parallel connection of the inductors. ${ }^{[11]}$

High-voltage-gain dc-dc converters using coupled inductors have been proposed for the integration of solar panels to $100-\mathrm{V}$ dc using single stage. For higher voltage, the stages can be added.

The converter makes use of Voltage multiplier cells derived from Dickson Charge pump. The voltage ratings of each capacitor is twice that of its previous VM cell. ${ }^{[12-14]}$ Also, the inductors $(\mathrm{L} 1, \mathrm{~L} 2)$ and switches $(\mathrm{S} 1, \mathrm{~S} 2)$ experience different current stresses whenever even number of VM cells are used.

\section{SIMULATION RESULTS}

\subsection{Zeta converter}

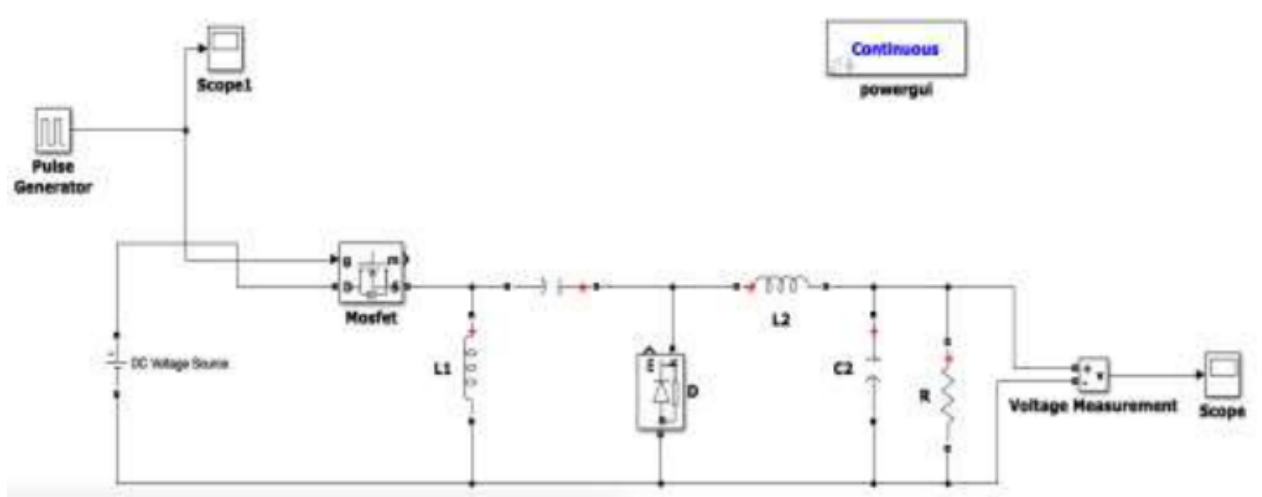

Figure 6 Simulation model of Zeta Converter

The zeta converter with a single input is shown in figure 6 . The output obtained from the rectifier is boosted using the Zeta Converter whose parameters are calculated using formulas for zeta converter. 
Table 1 Zeta converter design

\begin{tabular}{|l|c|}
\hline \multicolumn{1}{|c|}{ ATTRIBUTES } & VALUES \\
\hline INPUT VOLTAGE $\left(\mathrm{V}_{\mathrm{S}}\right)$ & $20 \mathrm{~V}$ \\
\hline OUTPUT VOLTAGE $\left(\mathrm{V}_{\mathrm{O}}\right)$ & $59 \mathrm{~V}$ \\
\hline SWITCHING FREQUENCY $\left(\mathrm{F}_{\mathrm{S}}\right)$ & $100 \mathrm{KHz}$ \\
\hline DUTY RATIO $(\mathrm{D})$ & $75 \%$ \\
\hline INDUCTOR L1 $=$ L2 & $60 \mathrm{mH}$ \\
\hline INPUT CAPACITOR & $1 \mu \mathrm{F}$ \\
\hline OUTPUT CAPACITOR & $2.5 \mu \mathrm{F}$ \\
\hline
\end{tabular}

The table 1 shows the input, output switching frequency, duty ratio, inductors and capacitor values designed for the zeta converter.

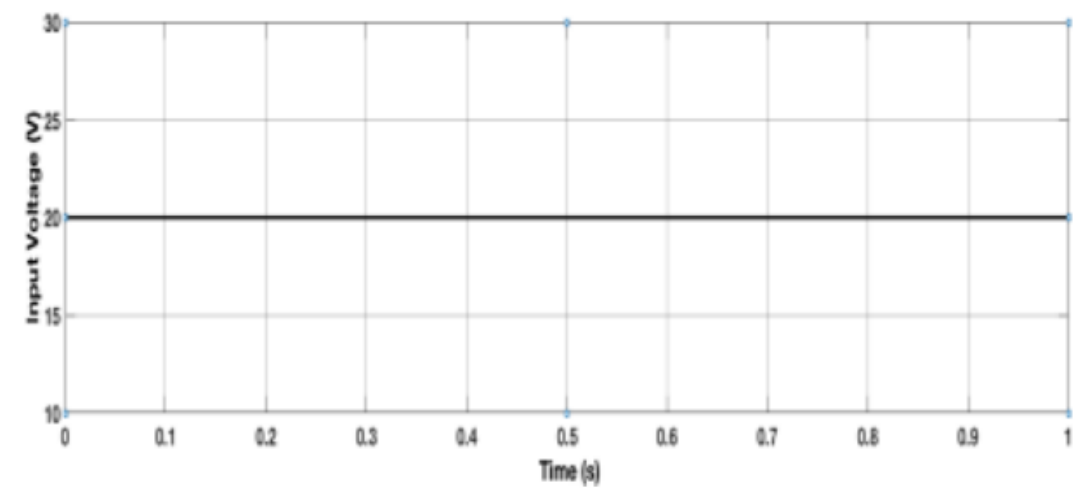

Figure 7 Input Voltage of Zeta Converter

The figure 7 shows the input voltage of 20V DC given to the Zeta converter.

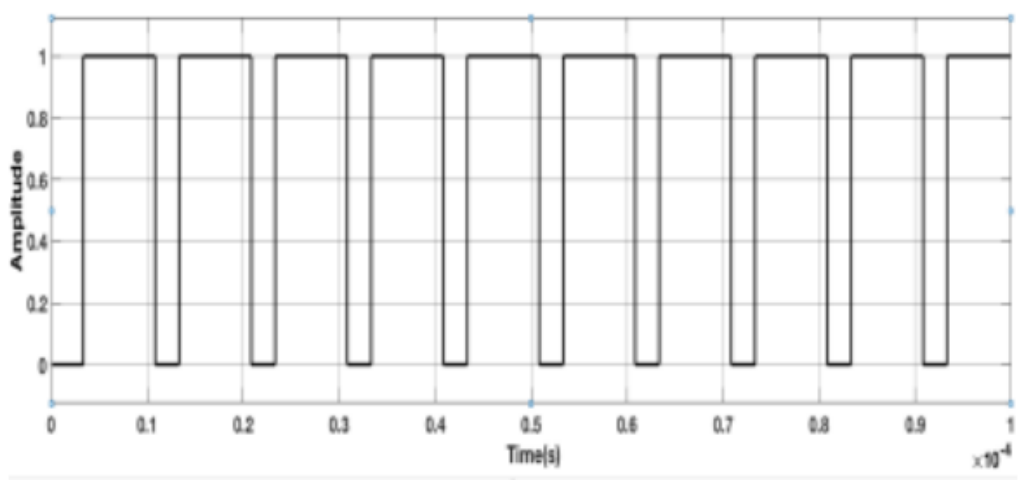

Figure 8 Pulses of Zeta Converter

The figure 8 shows the pulse given to the Zeta converter with switching frequency of $100 \mathrm{KHz}$ and $75 \%$ of duty ratio.

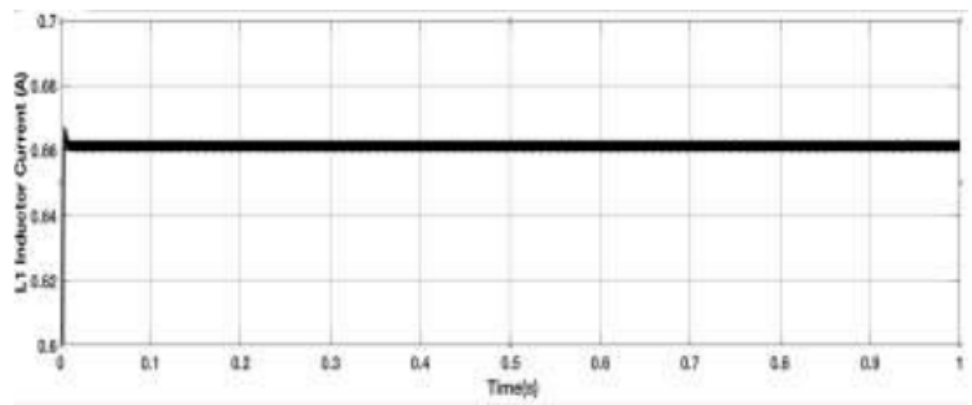

Figure 9 Inductor current L1 


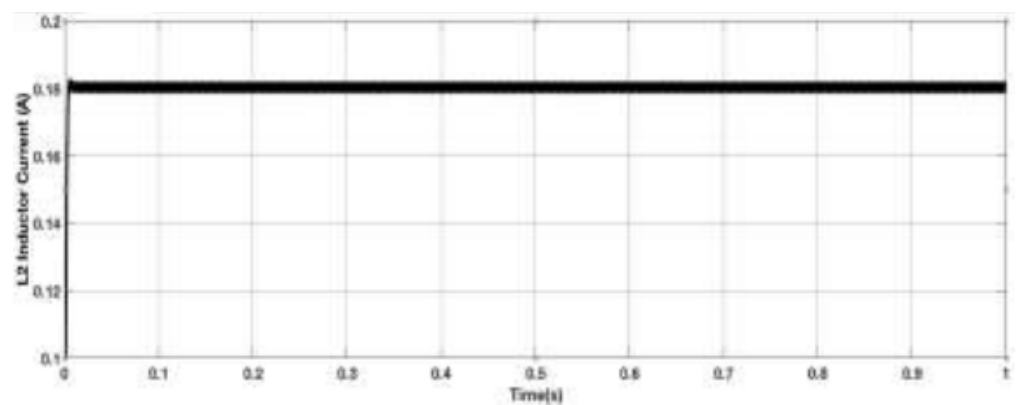

Figure 10 Inductor Current L2

The figure 9 and figure 10 shows the inductor current of the Zeta converter

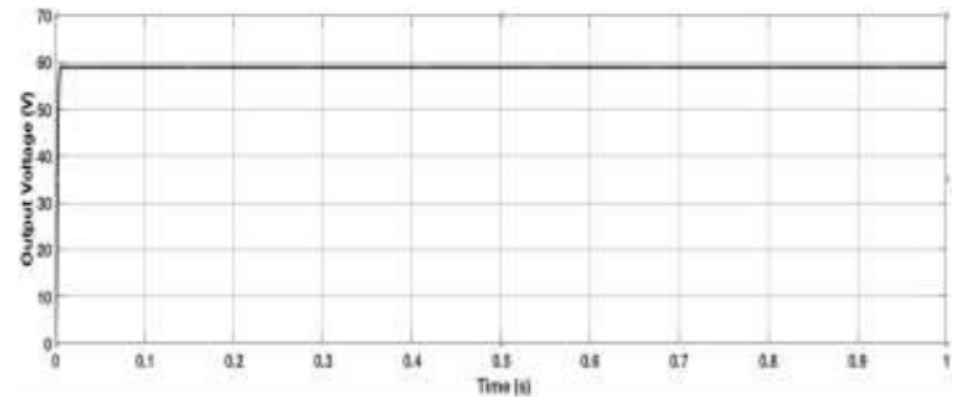

Figure 11 Output Voltage of Zeta Converter input.

The figure 11 show the output of the zeta converter which is boosted to $60 \mathrm{~V}$ from $20 \mathrm{~V}$

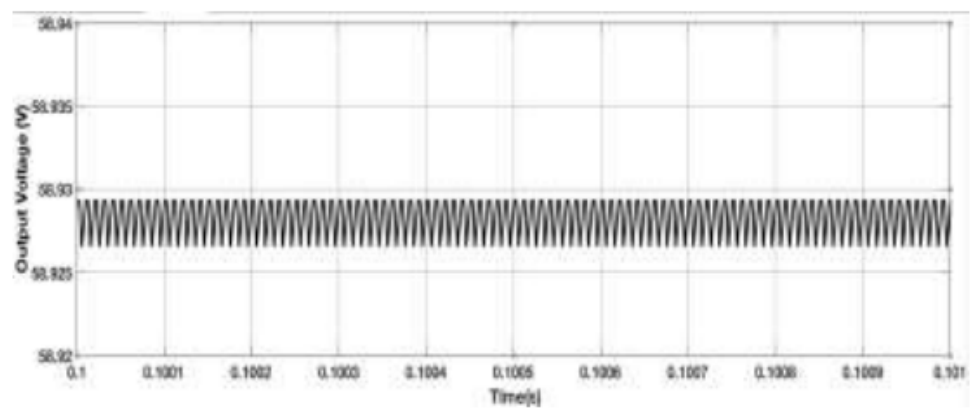

Figure 12:Output ripple of ZETA converter

The figure 12 shows the output voltage ripple which is around $0.01 \mathrm{~V}$.

The input source is connected to zeta converter. The inductor currents for both are similar. The pulse width for the zeta converter is given at $75 \%$ switching duty cycle with switching frequency $100 \mathrm{KHz}$ input $20 \mathrm{~V}$ and the output voltage of $60 \mathrm{~V}$ was obtained. The output voltage ripple was $0.01 \mathrm{~V}$.

\subsection{Single stage high voltage $\mathrm{DC}$-DC converter}

The high voltage DC-DC converter can be supplied from two inputs as well as using only one input source. When a single input is used for the proposed converter, switches $\mathrm{S}_{1}$ and $\mathrm{S}_{2}$ have the same switching duty cycle $d$ and are $180^{\circ}$ out of phase from each other.[10-14] The proposed converter with single source is shown in figure 13. 


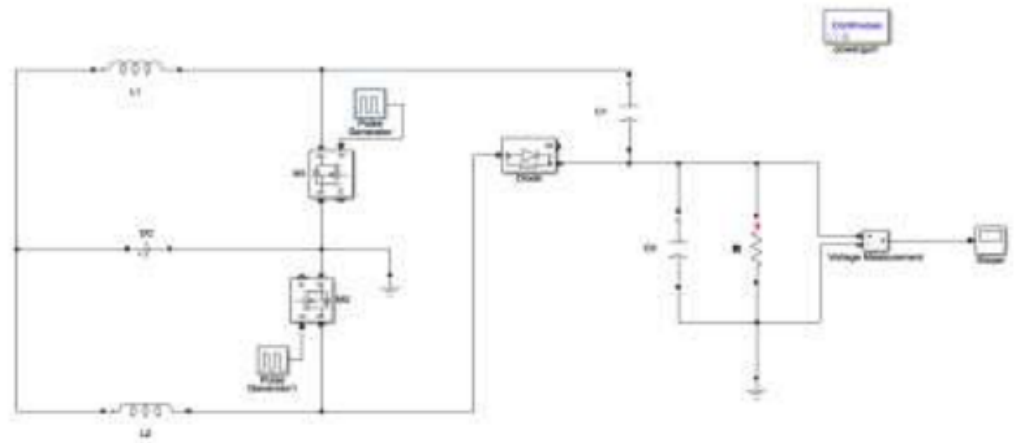

Figure 13 Simulation model of single stage High voltage gain converter

Table 2 High Voltage DC-DC Converter Design

\begin{tabular}{|l|c|}
\hline \multicolumn{1}{|c|}{ ATTRIBUTES } & VALUES \\
\hline INPUT VOLTAGE $\left(\mathrm{V}_{\mathrm{S}}\right)$ & $20 \mathrm{~V}$ \\
\hline OUTPUT VOLTAGE $\left(\mathrm{V}_{\mathrm{O}}\right)$ & $80 \mathrm{~V}$ \\
\hline SWITCHING FREQUENCY $\left(\mathrm{F}_{\mathrm{S}}\right)$ & $100 \mathrm{KHz}$ \\
\hline DUTY RATIO $(\mathrm{D})$ & $75 \%$ \\
\hline INDUCTOR L1 $=$ L2 & $100 \mathrm{mH}$ \\
\hline INPUT CAPACITOR & $60 \mu \mathrm{F}$ \\
\hline OUTPUT CAPACITOR & $60 \mu \mathrm{F}$ \\
\hline
\end{tabular}

The table 2 shows the input, output switching frequency, duty ratio, inductors and capacitor values designed for the high voltage DC-DC converter.

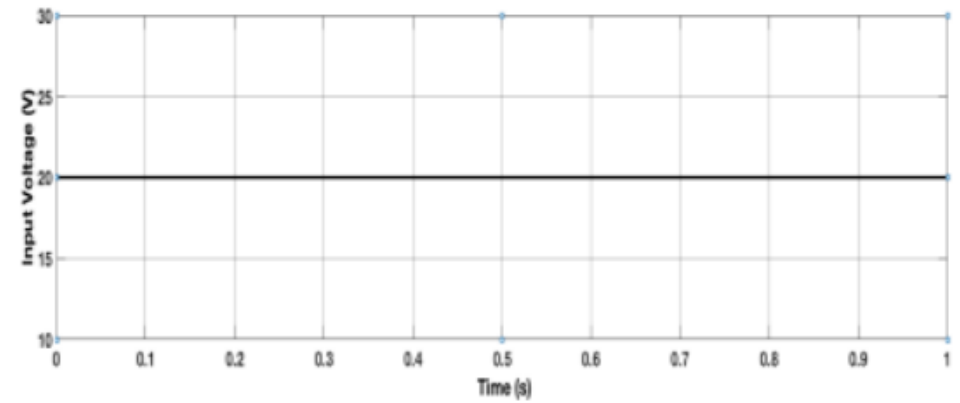

Figure 14 Input Voltage of Single stage High voltage gain converter

The figure 10 shows the input voltage of single stage high voltage gain converter which is 20V DC.
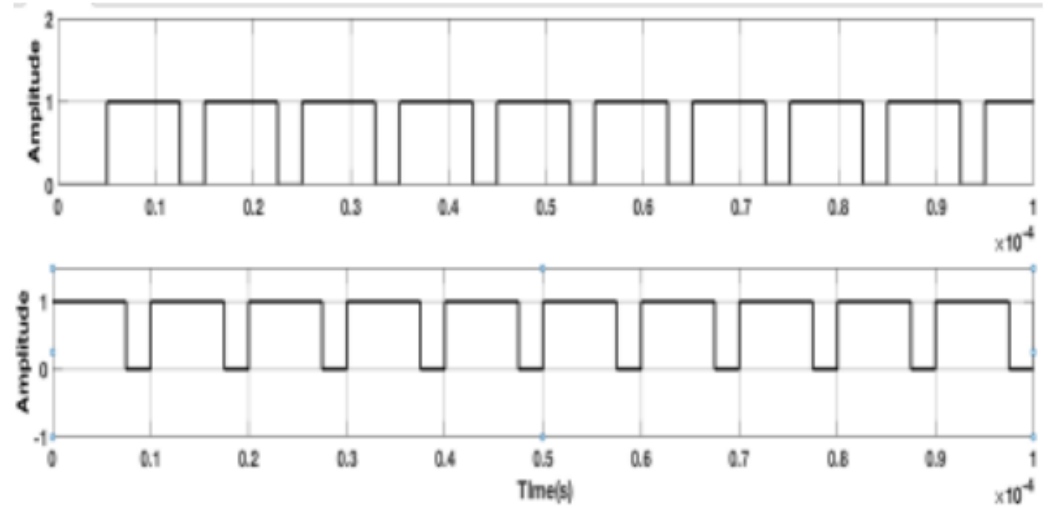

Figure 15 Pulses of Single stage High voltage gain converter

The pulses of the switches in the proposed converter are shown in figure 15 . 


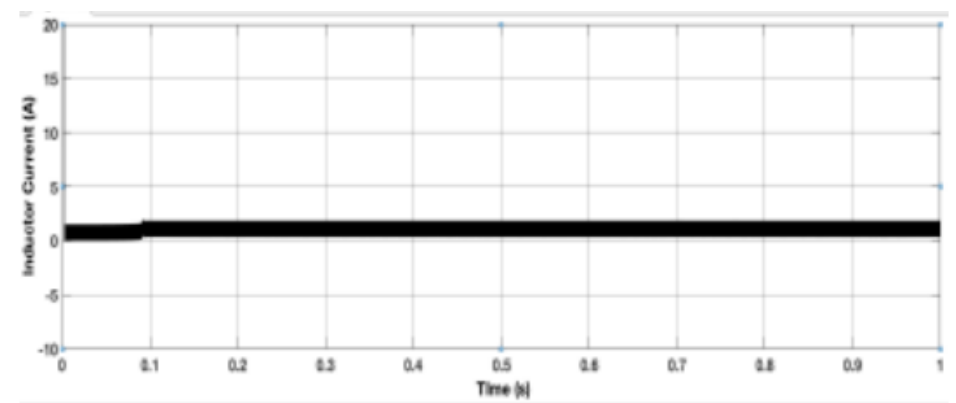

Figure 16 Inductor Current of Single stage High voltage gain converter

The figure 16 shows the inductor current of the Single stage High voltage gain converter

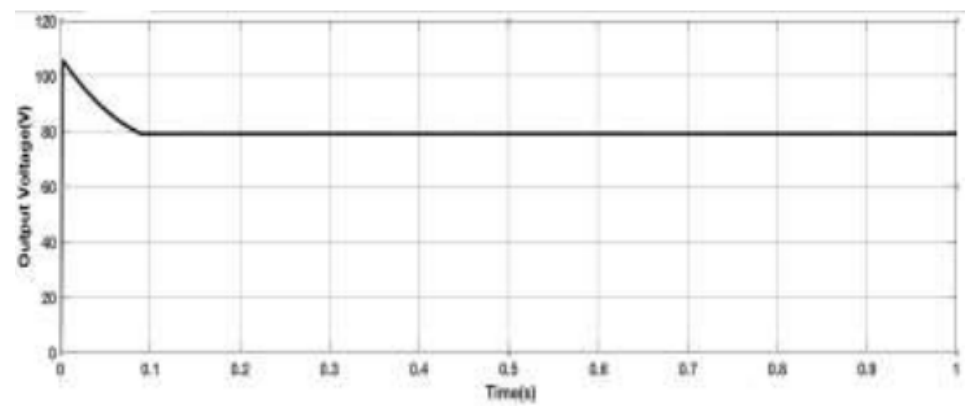

Figure 17 Output Voltage of Single stage High voltage gain converter

The figure 17 shows the output voltage of $80 \mathrm{~V}$ which is boosted from the input of $20 \mathrm{~V}$.

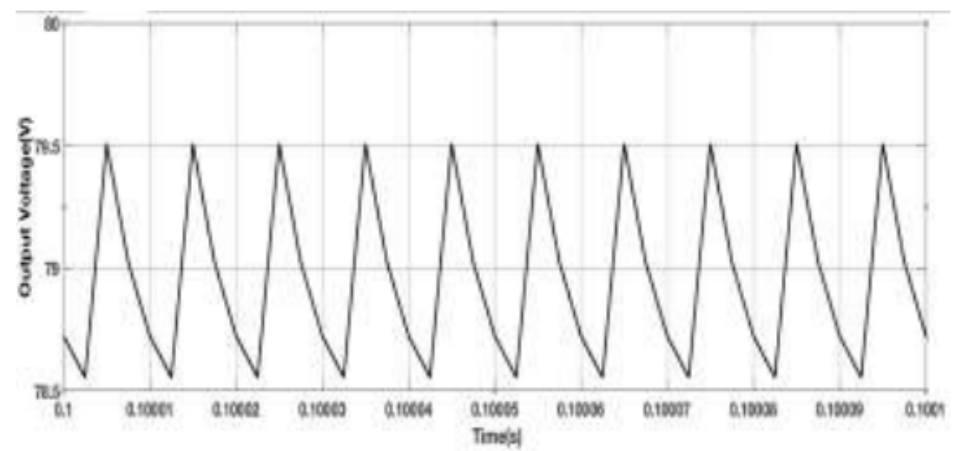

Figure 18 Output ripple of Single stage High voltage gain converter

The output voltage ripple of $0.08 \mathrm{~V}$ was shown in the figure 18 .

A high-voltage-gain dc-dc converter step up a $20 \mathrm{~V}$ input to $80 \mathrm{~V}$ output. This converter is based on a two-phase interleaved boost and the modified Dickson charge pump VM circuit. This interleaved structure reduces the input current ripple and distributes the current through each component. It can draw power from a single source as well as from two independent sources while offering continuous input current in both cases, making the converter well suited for renewable applications like solar. The converter is small in size and symmetric, i.e., the semiconductor components experience an efficient high step-up conversion through the voltage multiplier module and current stresses. 


\section{HARDWARE RESULT}

\subsection{Zeta Converter}

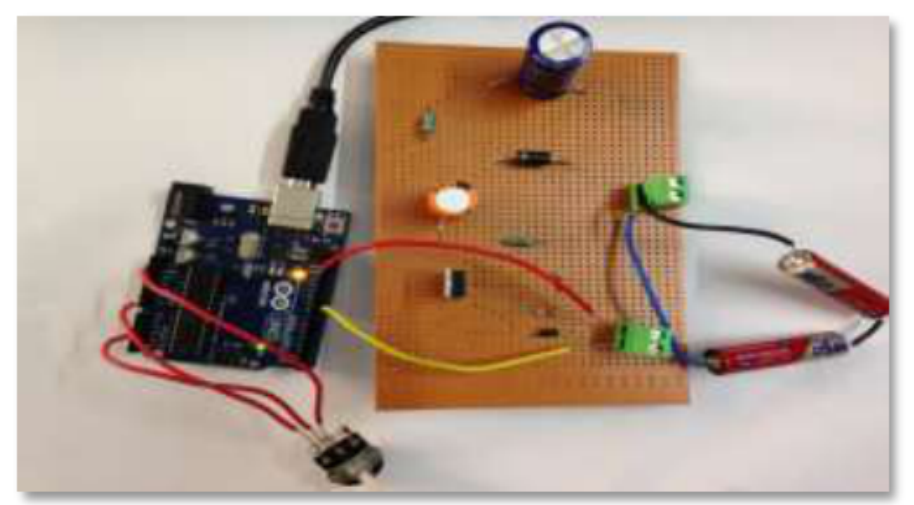

Figure 19 Zeta Converter

The figure 19 shows the zeta converter hardware. The IRF540N is used for zeta converter an advanced HEXFET N-channel power MOSFET, from International Rectifier. The device is extremely versatile with its performance capabilities and thus becomes ideal for numerous electronic applications.

The switching pulse to the MOSFET was provided by an Arduino board. Since the switching frequency required by our circuit was high, we preferred Arduino programming to a manual switch. The value of our Inductance was calculated to be $2.2 \mathrm{mH}$. The output capacitor $220 \mu \mathrm{F} / 160$ volts Electrolytic Non-Polarized Crossover Capacitor was used. The input capacitor $47 \mu \mathrm{F} / 60$ volts Electrolytic Non-Polarized Crossover Capacitor was used. In the prototype, the 3 volts is indicated by a 3 volt battery that is connected to the zeta converter. The output voltage of $30 \mathrm{~V}$ was obtained

\subsection{Single stage high voltage DC-DC converter}

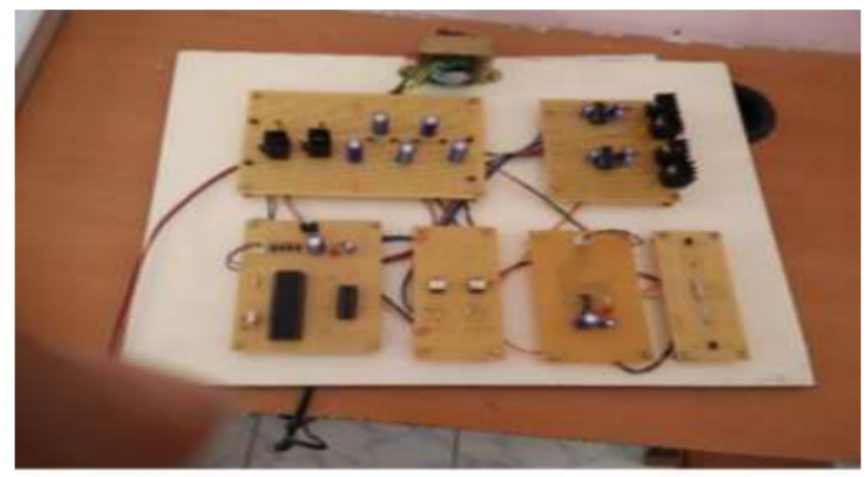

Figure 20 High Voltage DC-DC Converter

The IRF540N is used for high voltage DC-DC converter an advanced HEXFET Nchannel power MOSFET, from International Rectifier. The device is extremely versatile with its performance capabilities and thus becomes ideal for numerous electronic applications. The switching pulse to the MOSFET was provided by PIC16F877A. It perfectly fits many uses, from automotive industries and controlling home appliances to industrial instruments, remote sensors, electrical door locks and safety devices. It is also ideal for smart cards as well as for battery supplied devices because of its low consumption. Multiplier cells of the Dickson's charge pump are fed from the drain of MOSFET1 and source of MOSFET2. This Dickson's 
charge pump consists of 4 sets of multiplier cells which have parallel connected diodes and capacitors. Diode IN4007 with a resistor[1Kohm] and a capacitor connected in series with the boosted output from the Dickson's charge pump to reduce the noise. Which are further connected to the inverter circuit. Monolithic gate driver circuits [FAN7392] are used which are fed by the buffer circuit. In the prototype $20 \mathrm{~V}$ input is connected to the high voltage DCDC converter. The output voltage of $80 \mathrm{~V}$ was obtained. Driver circuit needs $12 \mathrm{~V}$ and $5 \mathrm{~V}$. Microcontroller need 5V supply, so $230 \mathrm{~V}$ AC supply is first step down in to $15 \mathrm{~V}$ by using step down transformer. Then this $15 \mathrm{~V}$ AC is converted in to $\mathrm{DC}$ by using Full bridge rectifier which has high efficiency than all other methods. This $15 \mathrm{~V}$ DC is converting into $12 \mathrm{~V} \mathrm{DC}$ and $5 \mathrm{v}$ DC by using 7812 and 7805 regulator respectively. The capacitor is used to provide smooth variation in voltage.

\section{CONCLUSION}

In this paper was presented a comparative study of DC-DC converters in Zeta and single stage high voltage topologies. The operation equations of main parameters were presented. The simulation results of both the converters are presented here. The input voltage is boosted in both the converters. The analysis of Zeta and single stage high voltage DC-DC converter is performed using the given design values for inductance and capacitance. The ripple free output voltage is obtained. The output obtained is ripple free with fewer losses. The steady state is obtained very early during the operation which increases the efficiency of this model. The Zeta converter thus provides a substantial boost of the input voltage which increases the overall efficiency of operation of this circuit. The high-voltage-gain dc-dc converter is based on a two-phase interleaved boost and the modified Dickson charge pump VM circuit, which reduces the input current ripple and distributes the current through each component. The input, output and output voltage ripple values of the both the converters were given in the table 3.

Table 3 Comparison Values

\begin{tabular}{|l|c|c|}
\hline Attributes & Zeta Converter & $\begin{array}{l}\text { Single Stage High Voltage DC-DC } \\
\text { Converter }\end{array}$ \\
\hline Input Voltage $\left(\mathrm{V}_{\mathrm{S}}\right)$ & $20 \mathrm{~V}$ & $20 \mathrm{~V}$ \\
\hline Output Voltage $\left(\mathrm{V}_{\mathrm{O}}\right)$ & $59 \mathrm{~V}$ & $79.5 \mathrm{~V}$ \\
\hline $\begin{array}{l}\text { Output Ripple Voltage } \\
\left(\Delta \mathrm{V}_{\mathrm{O}}\right)\end{array}$ & $0.01 \mathrm{~V}$ & $0.08 \mathrm{~V}$ \\
\hline
\end{tabular}

\section{REFERENCES}

[1] J. T. Bialasiewicz, "Renewable energy systems with photovoltaic power generators: Operation and modeling," IEEE Trans. Ind. Electron., vol. 55, no. 7, pp. 2752-2758, Jul. 2008.

[2] Environmental Impacts of Renewable Energy Technologies(EwaKlugmann-Radziemska, Gdansk University of Technology, Faculty of Chemistry

[3] T. Kefalas and A. Kladas, "Analysis of transformers working under heavily saturated conditions in grid-connected renewable energy systems," IEEE Trans. Ind. Electron., vol. 59, no. 5, pp. 2342-2350, May 2012

[4] Trends of power electronics on renewable energy systems(P. Gazis, G. A. Vokas, St. Papathanasiou, Electronic Engineer, T.E.I. Piraeus) 
[5] R. J. Wai and W. H. Wang, "Grid-connected photovoltaic generation system," IEEE Trans. Circuits Syst. I, Reg. Papers, vol. 55, no. 3, pp. 953-964, Apr. 2008.

[6] The comparative study of Buck-boost, Cuk, Sepic and Zeta converters for maximum power point tracking photovoltaic using P\&O method, Soedibyo ; Budi Amri ; Mochamad Ashari, 2015 2nd International Conference on Information Technology, Computer, and Electrical Engineering (ICITACEE)

[7] Comparison on performance between synchronous single-ended primary-inductor converter (SEPIC) and synchronous Zeta converter Kaweepoj Woranetsuttikul ; Kittapas Pinsuntia; Nattawat Jumpasri; Taywin Nilsakorn; Werachet Khan-ngern 2014 International Electrical Engineering Congress (iEECON)

[8] Design, analysis and performance of Zeta converter in renewable energy systems Ahana Malhotra ; Prerna Gaur; Shitiz Vij ; Charvi Malhotra 2016 3rd International Conference on Computing for Sustainable Global Development (INDIACom)

[9] Modeling and simulation analysis of PV fed Cuk, Sepic, Zeta and Luo DC-DC converter Deepak; Rupendra Kumar Pachauri; Yogesh K. Chauhan 2016 IEEE 1st International Conference on Power Electronics, Intelligent Control and Energy Systems (ICPEICES)

[10] Fully Integrated Dickson Charge Pumps with Optimized Power Efficiency, Jan Doutreloigne, Proceedings of the World Congress on Engineering and Computer Science 2010 Vol II

[11] Y. Xiong, X. Cheng, Z. J. Shen, C. Mi, H. Wu, and V. K. Garg, "Prognostic and warning system for power-electronic modules in electric, hybrid electric, and fuel-cell vehicles," IEEE Trans. Ind. Electron., vol. 55, no. 6, pp. 2268-2276, Jun. 2008.

[12] A. K. Rathore, A. K. S. Bhat, and R. Oruganti, "Analysis, design and experimental results of wide range ZVS active-clamped L-L type currentfed DC/DC converter for fuel cells to utility interface,” IEEE Trans. Ind.Electron., vol. 59, no. 1, pp. 473-485, Jan. 2012.

[13] T. Zhou and B. Francois, "Energy management and power control of a hybrid active wind generator for distributed power generation and grid integration," IEEE Trans. Ind. Electron., vol. 58, no. 1, pp. 95-104, Jan. 2011.

[14] N. Denniston, A. M. Massoud, S. Ahmed, and P. N. Enjeti, "Multiple module high-gain high-voltage DC-DC transformers for offshore wind energy systems," IEEE Trans. Ind. Electron., vol. 58, no. 5, pp. 1877-1886, May 2011. 